\title{
ЗАПРОВАДЖЕННЯ ЗМІШАНОЇ ФОРМИ НАВЧАЛЬНОГО ПРОЦЕСУ НА КАФЕДРІ ГОСПІТАЛЬНОЇ ХІРУРГІЇ ЗАПОРІЗЬКОГО ДЕРЖАВНОГО МЕДИЧНОГО УНІВЕРСИТЕТУ
}

\author{
A. O. Nykonenko, S. R. Vildanov \\ Zaporizhzhia State Medical University \\ INTRODUCTION OF THE MIXED FORM OF THE EDUCATIONAL \\ PROCESS AT THE DEPARTMENT OF HOSPITAL SURGERY OF \\ ZAPORIZHZHIA STATE MEDICAL UNIVERSITY
}

\begin{abstract}
Анотація. У статті наведено досвід організації дистанційної освіти на кафедрі госпітальної хірургії Запорізького державного медичного університету з впровадженням новітніх технологій навчання по хірургічній спеціальності.

Microsoft Teams - центр командної роботи в сервісі Microsoft Office 365. Тут інтегровано користувачів, вміст та інструменти, необхідні команді для ефективної роботи і взаємодії. Для студентів завантажені електронні матеріали для підготовки. Автоматичний підрахунок процента правильних відповідей нівелює суб’єктивність оцінювання. Інтерактивні відеоконференції у режимі реального часу дають можливість повноцінного усного опитування та розбору клінічних випадків з одночасною презентацією фото- та відеоматеріалів.

На базі платформи edX ЗДМУ створено онлайн-курси за вибором, серед яких студент самостійно обирає той, що складає для нього найбільший інтерес. Для написання історії хвороби використовується віртуальний симулятор пацієнта Body Interact. Останній укомплектований різноманітними сценаріями з клініки та невідкладних станів.

Внаслідок проведеного аналізу автори дійшли висновків, що розвиток інформаційних технологій розширює можливості як для самоосвіти студентів, так і для впровадження новітніх форм викладання в педагогічний процес. Успішна педагогіка та ефективна освіта мають бути інтерактивними. Обговорення є однією з найефективніших форм навчального процесу і, вірогідно, саме тому залишається незмінною складовою освіти. Анонімне анкетування та спільні круглі столи (в тому числі в онлайнвідеоформаті) викладачів та студентського активу щодо освітнього процесу є дієвим механізмом для гнучкого розвитку освіти й ефективного компромісу між існуючими карантинними обмеженнями та потребами студентства.
\end{abstract}

Ключові слова: дистанційне навчання; навчальний процес.

Abstract. The article presents the experience of organizing distance education at the Department of Hospital Surgery of Zaporizhzhia State Medical University with the introduction of the latest learning technologies in the surgical specialty.

Microsoft Teams is the teamwork center in Microsoft Office 365. It integrates the users, content and tools that team needs to work effectively and for interaction. Electronic training materials are downloaded for students. Automatic calculation of the percentage of correct answers eliminates the subjectivity of the assessment. Interactive real-time video conferences provide the opportunity for a full oral interview and analysis of clinical cases with the simultaneous presentation of photos and videos.

On the basis of the edX platform ZSMU it is created online courses of choice, among which the student independently chooses the one that is of greatest interest to him.

A virtual patient simulator Body Interact is used for writing a medical history. The latter is equipped with various scenarios from the clinic and emergencies.

As a result of the analysis, the authors came to the conclusions that the development of information technology expands the opportunities for both self-education of students and for the introduction of new forms of teaching in the pedagogical process. Successful pedagogy and effective education must be interactive. Discussion is one of the most effective forms of the educational process and, probably, that is why it remains an invariable component of education. Anonymous questionnaires and joint roundtables (including online video format) of lectures and students as for the educational process are an effective mechanism for the flexible development of education and an effective compromise between existing quarantine restrictions and student needs.

Key words: distance learning; educational process.

\footnotetext{
(c) А. О. Никоненко, С. Р. Вільданов
} 
Вступ. Пандемія COVID-19, котра вразила всі сфери нашої життєдіяльності, внесла свої зміни і в навчальний процес. В одній із своїх промов Джон Кеннеді сказав: «Китайці використовують два ієрогліфи для написання слова «криза»: один означає «небезпека», інший - «можливість». Під час кризи пам'ятай про небезпеку, але розпізнавай можливості». Розвиток інформаційних технологій диктує вищим навчальним закладам нові виклики для вдосконалення та пропонує ряд революційних можливостей для покращення навчального процесу [3].

Законом України від 30.03.2020 р. № 540-IX «Про внесення змін до деяких законодавчих актів України, спрямованих на забезпечення додаткових соціальних та економічних гарантій у зв'язку з поширенням коронавірусної хвороби (COVID-19)» внесені зміни до статті 60 Кодексу законів про працю України, якими врегульовано запровадження гнучкого режиму часу і дистанційної (надомної) роботи на підприємствах, в установах, організаціях $[4,5]$.

У Європі дистанційна форма навчання з'явилася досить давно і має велику популярність серед студентів через її економічні показники і навчальну ефективність. Дистанційну форму навчання ще називають «освітою протягом усього життя», оскільки вона дає свободу вибору місця, часу та темпу навчання [1].

Досягнути відповідних результатів дозволяє впровадження в навчальний процес студентів новітніх та інтерактивних технологій навчання, арсенал яких на сучасному етапі поповнився значною кількістю методик. Саме їх використання дозволяє значно покращити ефективність навчання [2].

Мета статті - на основі власного досвіду провести аналіз впровадження та використання новітніх технологій освіти на кафедрі госпітальної хірургії Запорізького державного медичного університету. Визначити можливості дистанційної освіти та окреслити перспективи використання інформаційних технологій у викладанні клінічних дисциплін хірургічного напрямку.

Теоретична частина. Співробітники кафедри госпітальної хірургії ЗДМУ провели кропітку роботу для створення студентам умов для максимально ефективного навчання дистанційно. На кафедральній сторінці сайту ЗДМУ розміщені всі необхідні матеріали для кожного факультету, які включають розклади і тематики практичних занять та лекцій, електронні версії матеріалів для підготовки до практичних занять, презентації лекцій.
Кафедра госпітальної хірургії є випускною кафедрою, тому особлива увага приділяється підготовці до ліцензійного державного іспиту «Крок 2». 3 цією метою щорічно оновлюється база тестів з хірургії. Для засвоєння матеріалу вважаємо надважливим НЕ «зазубрювання» тестів, а розуміння, ЧОМУ відповідь правильна. Тому був розроблений блок тестів «Крок 2» з докладними коментарями та ілюстраціями до кожного тесту, що пояснюють та аргументують вибір коректної відповіді на запитання.

Використання Microsoft Teams надзвичайно розширило горизонти як навчального, так і педагогічного процесу. Microsoft Teams - центр командної роботи в сервісі Microsoft Office 365. Тут інтегровано користувачів, вміст та інструменти, необхідні команді для ефективної роботи та взаємодії. Для студентів завантажені електронні матеріали для підготовки. Тестовий контроль має гнучкі параметри й дає викладачу можливість змінювати порядок тестових питань та відповідей, час на вирішення. Автоматичний підрахунок процента правильних відповідей нівелює суб’єктивність оцінювання. Окрім стандартних тестів, ми використовуємо багаторівневі ситуаційні завдання. Такі задачі складаються $з$ декількох тестових завдань. Перехід на наступний рівень можливий тільки після подолання попереднього. Як правило, це логічна послідовність, що включає спочатку клінічну картину (скарги, анамнез та дані фізикального обстеження). Далі пропонується вибрати найбільш інформативний метод діагностики. На наступному етапі інтерпретуються діагностичні дані (наприклад, томограма, сонограма та ін.). Наступний крок - діагноз. У кінці задачі пропонується призначити лікування. Завдання такого типу, на наш погляд, сприяють розвитку однієї з провідних якостей та досягненню основної мети навчання у медичному ЗВО - формування клінічного мислення. Ми успішно екстраполювали досвід використання таких багатоступеневих завдань і в ліцензійні державні випускні іспити. Головними перевагами вважаємо рівність умов, «неупереджене» автоматичне оцінювання, достатньо швидке отримання результатів. Таким чином скоординовано та об’ єктивно реалізуємо екзамени 3 дотриманням карантинних вимог без потреби скупчення студентів в аудиторіях.

Головною ж перевагою Microsoft Teams $є$ можливість інтерактивних відеоконференцій у режимі реального часу. Це дає можливість повноцінного усного опитування і розбору клінічних випадків 3 
одночасною презентацією фото- та відеоматеріалів. Дані можливості активно використовуються у роботі кафедрального студентського гуртка, де студенти презентують доповіді з наступним обговоренням та активною дискусією.

Після відеозв’язку програма автоматично завантажує звіт про участь, де відображено час приєднання, виходу та підраховується тривалість перебування на занятті кожного студента. Ці звіти зберігаються та використовуються для аналізу відвідуваності занять. Співробітники ректорату і деканату мають можливість у будь-який час підключитися до лекції або практичного заняття. Таким чином реалізується контроль відвідуваності та активності студентів під час навчання. Взаємовідвідування занять викладачами дозволяє обмінюватися педагогічним досвідом та підвищувати рівень викладання.

Проведення відеоконференцій було інтегровано не тільки безпосередньо у викладання, а й в організацію освітнього процесу. Так проводилися кафедральні наради, засідання факультетських та вчених рад університету тощо. Ба більше, дані можливості можна використовувати навіть на етапах захисту дисертаційних робіт.

Для ефективної самостійної роботи студенти мають бути зацікавлені в ній. Серед переліку створених курсів за вибором студент самостійно обирає той, що складає для нього найбільший інтерес. Це мотивує до навчання, оскільки майбутній фахівець обирає ту дисципліну, якою цікавиться та хоче опанувати.

На кафедрі госпітальної хірургії на базі платформи еdX ЗДМУ створено онлайн-курси «Судинна хірургія» та «Основи трансплантології» для студентів V-VI курсів. Онлайн-курси включають навчальні матеріали, структуровані за темами (у текстовому форматі, фото, 3D анімаційні та відеоматеріали), які оформлені українською та англійською мовами для вітчизняних та іноземних англомовних студентів відповідно. В кінці курсу студенти проходять онлайн-тестування, результати якого підраховуються автоматично та відображаються в сертифікаті закінчення курсу. Це дає можливість викладачу зосередитися на реалізації та контролі практичних навичок студентів. Впровадження комп’ютерних технологій у вивчення та контроль теоретичної частини, з одного боку, надає можливість гнучкого графіка індивідуального опанування матеріалу, 3 іншого - дисциплінує та стимулює самосвідомість.
Проходження курсів за вибором, на наш погляд, допомагає студенту свідомо ствердитися у виборі майбутньої спеціальності.

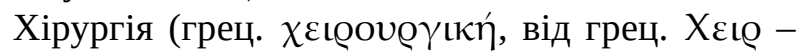
рука і грец. Оv@үıќ - робити). Тому окрема увага приділяється практичним навичкам. Ha YouTube каналі кафедри для студентів доступні відео фізикального обстеження пацієнтів та практичних навичок, зняті співробітниками кафедри.

Для написання історії хвороби використовується віртуальний симулятор пацієнта Body Interact. Останній укомплектований різноманітними сценаріями з клініки та невідкладних станів. Технологія дозволяє поспілкуватися з віртуальним пацієнтом, провести фізикальне обстеження, зробити необхідні лабораторні та інструментальні тести, встановити діагноз і призначити лікування, вибравши дозування препарату з урахуванням маси тіла, зросту пацієнта. При цьому клінічний стан віртуального пацієнта змінюється залежно від наданої допомоги. Тому для студентів є унікальна можливість зрозуміти коректність своїх дій i, проаналізувавши допущені помилки, зробити висновки на майбутнє. Найціннішою особливістю системи віртуального пацієнта $є 50$ віддалених точок доступу до сервера Body Interact, що надає можливість дистанційної роботи в режимі онлайн-тренінгу.

Для того щоб освіта була в тренді, необхідний діалог та взаєморозуміння потреб і вимог між освітянами та студентством. Використання googleформ для регулярного анонімного анкетування, як студентів, так і професорсько-викладацького контингенту, щодо якості та перспектив проведення лекційних та практичних занять дозволяє досягти комплаєнсу в навчальному процесі. Вочевидь, певні класичні формати на сьогодні втрачають актуальність. Розвиток технологій, всеосяжність мережі Internet сприяють доступності інформації. Нівелюється потреба відвідувати бібліотеку, змінюються вимоги до акцентів під час викладання матеріалу. Зокрема, це стосується лекцій. Так, згідно з анонімним опитуванням студентів ЗДМУ, втрачається зацікавленість аудиторії щодо етіопатогенезу захворювань та класифікації нозологічних форм. Натомість спостерігається високий інтерес до розбору клінічних прикладів. Сучасний стрімкий технологічний розвиток дозволяє активно включати у викладацьку діяльність фото, анімаційні та відеоматеріали. Але навіть у такому форматі монолог лектора недостатньо ефективний. Інтерактивна форма 
із залученням аудиторії до обговорення та дискусії дозволяє проводити заняття найбільш ефективно.

Враховуючи тенденцію до імплементації та поширення телемедицини, дистанційна медична освіта адаптує майбутніх фахівців до подальшої клінічної трудової діяльності.

Таким чином, необхідна мобільність вектора розвитку освіти, відповідно до вимог часу. Важливо дійти спільного знаменника між вимогами викладачів та потребами студентів. Це дасть змогу освіті бути в тренді сучасних вимог.

Висновки та перспективи подальших досліджень. 1. Розвиток інформаційних технологій розширює можливості як для самоосвіти студентів, так і для впровадження новітніх форм викладання в педагогічний процес.

2. Успішна педагогіка та ефективна освіта мають бути інтерактивними. Обговорення є однією 3 найефективніших форм навчального процесу i, вірогідно, саме тому залишається незмінною складовою освіти.

3. Анонімне анкетування та спільні круглі столи (в тому числі в онлайн-відеоформаті) викладачів та студентського активу щодо освітнього процесу $\epsilon$ дієвим механізмом для гнучкого розвитку освіти й ефективного компромісу між існуючими карантинними обмеженнями та потребами студентства.

Перпективними є педагогічні конференції, зокрема між медичними ЗВО для обміну досвідом викладання та підвищення якості освіти.

Досвід онлайн-відеоконференцій з демонстрацією цифрових записів та скан-копій медичної документації доцільно екстраполювати у роботу клінічних баз медичних 3ВО в якості телемедичної складової консультативного прийому. Це, у свою чергу, полегшить комунікацію як з пацієнтами, так і між клініками.

імені Л. Я. Ковальчука / С. Й. Гриценко, А. Д. Беденюк, В. Б. Доброродній, А. Є. Бурак // Медична освіта. 2020. - № 3. - С. 21-23.

4. Про внесення змін до деяких законодавчих актів України, спрямованих на забезпечення додаткових соціальних та економічних гарантій у зв'язку з поширенням коронавірусної хвороби (COVID-19) : Закон України від 30.03.2020 р. № 540-IX [Електронний ресурс]. - Режим доступу : https://zakon.rada.gov.ua/laws/ show/540-20\#Text

5. Щодо тимчасового переходу на дистанційне навчання : Лист МОН України від 12.10.2020 р. № 1/9-576 [Електронний ресурс]. - Режим доступу : https://mon.gov. ua/ua/npa/shodo-timchasovogo-perehodu-na-distancijnenavchannya.

\section{References}

1. Borisyuk, I.Yu., \& Kutasevich, N.V. (2020). Dystantsiyne navchannya - yak vazhlyva lanka suchasnoyi medychnoyi systemy vyshchoyi osvity [Distance learning - as an important part of the modern medical system of higher education]. Aktualni pytannya vyshchoyi medychnoyi (farmatsevtychnoyi) osvity $v$ Ukrayini - Current issues of higher medical (pharmaceutical) education in Ukraine: Proceedings of the XVII All-Ukrainian Scientific and Practical Conference with international participation. Ternopil: TNMU [in Ukrainian].

2. Gerasymchuk, P.O., Pavlyshyn, A.V., \& Fira, D.B. (2021). Vprovadzhennya innovatsiynykh tekhnolohiy u

vykladannya navchalnoyi dystsypliny na kafedri zahalnoyi khirurhiyi [Implementation of innovative technologies of teaching at the department of general surgery]. Medychna osvita - Medical Education, 1, 17-22 [in Ukrainian].

3. Grytsenko, S.Y., Bedeniuk, A.D., Dobrorodniy, V.B., \& Burak, A.Ye. (2020). Dosvid provedennya dystantsiynykh onlayn-seminariv pid chas karantynu na kafedri khirurhiyi №1 z urolohiyeyu, maloinvazyvnoyu khirurhiyeyu ta neyrokhirurhiyeyu imeni L.Ya. Kovalchuka [Experience of conducting distance online seminars during quarantine distance at the L. Ya. Kovalchuk department of surgery No. 1 with urology, minimally invasive surgery and neuro- 
surgery]. Medychna osvita - Medical Education, 3, 21-23 [in Ukrainian].

4. Zakon Ukrayiny Pro vnesennya zmin do deyakykh zakonodavchykh aktiv Ukrayiny, spryamovanykh na zabezpechennya dodatkovykh sotsialnykh ta ekonomichnykh harantiy u zvyazku z poshyrennyam koronavirusnoyi khvoroby (COVID-19) vid 30.03.2020 r. № 540-IX [The Law of Ukraine On Amendments to Certain Legislative Acts of Ukraine Aimed at Providing Additional Social and Economic Guarantees in Connection with the Spread of Coronavirus Disease (COVID-19) dated 30.03.2020 No. 540-IX]. zakon.rada.gov.ua. Retrieved from: https:// zakon.rada.gov.ua/laws/show/540-20\#Text [in Ukrainian]. 5. Lyst MON Ukrayiny Shchodo tymchasovoho perekhodu na dystantsiyne navchannya vid 12.10.2020 r. No. 1/9-576 [Letter of the Ministry of Education and Science of Ukraine Regarding the temporary transition to distance learning dated 12.10.2020 No. 1/9-576]. mon.gov.ua. Retrieved from: https:/mon.gov.ua/ua/npa/shodo-timchasovogo-perehoduna-distancijne-navchannya [in Ukrainian].

Електронна адреса для листування: vildanov009@gmail.com 